Article

\title{
In-Vivo In-Vitro Screening of Ocimum basilicum L. Ecotypes with Differential UV-B Radiation Sensitivity
}

\author{
Haana Mosadegh ${ }^{1}$, Alice Trivellini ${ }^{1, *(\mathbb{D})}$, Rita Maggini ${ }^{2}$, Antonio Ferrante $^{3}{ }^{\circledR}$, Luca Incrocci ${ }^{2}(\mathbb{D}$ and \\ Anna Mensuali $1, *$ (D) \\ 1 Institute of Life Sciences, Scuola Superiore Sant'Anna, Pz. Martiri della Libertà 33, 56127 Pisa, Italy; \\ hana_mosadegh@yahoo.com \\ 2 Department of Agriculture, Food and Environment, Università Degli Studi di Pisa, Via del Borghetto 80, \\ 56124 Pisa, Italy; rita.maggini@unipi.it (R.M.); luca.incrocci@unipi.it (L.I.) \\ 3 Department of Agricultural and Environmental Sciences, Università degli Studi di Milano, \\ 20133 Milano, Italy; antonio.ferrante@unimi.it \\ * Correspondence: alice.trivellini@gmail.com (A.T.); a.mensuali@santannapisa.it (A.M.)
}

Citation: Mosadegh, H.; Trivellini, A.; Maggini, R.; Ferrante, A.; Incrocci, L.; Mensuali, A. In-Vivo In-Vitro Screening of Ocimum basilicum L. Ecotypes with Differential UV-B Radiation Sensitivity. Horticulturae 2021, 7, 101. https://doi.org/ 10.3390/horticulturae7050101

Academic Editor: Federica Blando

Received: 31 March 2021

Accepted: 2 May 2021

Published: 7 May 2021

Publisher's Note: MDPI stays neutral with regard to jurisdictional claims in published maps and institutional affiliations.

Copyright: (c) 2021 by the authors. Licensee MDPI, Basel, Switzerland. This article is an open access article distributed under the terms and conditions of the Creative Commons Attribution (CC BY) license (https:/ / creativecommons.org/licenses/by/ $4.0 /)$.

\begin{abstract}
Elevated UV-B radiation (UV-B) has been previously reported to affect plant development, physiology, and promote the biosynthesis of UV-absorbing compounds. Sweet basil (Ocimum basilicum L.) is an aromatic herb, widely cultivated worldwide for its use in the food, pharmaceuticals, and cosmetics industry. This species exhibits high diversity among different ecotypes based on their geographical locations. There has been little research on intra-specific photosynthetic and metabolic differences in UV-B tolerance across ecotypes from different geographical areas. This study evaluated the protection responses to high UV-B radiation of nine O. basilicum accessions with different geographic origins. Specifically, the changes in chlorophyll $a$ fluorescence parameters and the leaf rosmarinic acid (RA) compound were assessed using an "in vivo-vitro system" in a closed-type plant production system. Our results revealed a significant variation in UV-B protection mechanisms among accessions when plants were treated with high UV-B doses. The accumulation of RA increased significantly by UV-B light treatment in OCI142, OCI148, OCI30, OCI160, and OCI102, with the highest concentration measured in OCI160 plants. This ecotype showed the highest value of the Fv / Fm ratio, 0.70 , after $48 \mathrm{~h}$. Recovery of leaf functionality was more rapid in OCI160 than in other sweet basil accessions, which may indicate better photosynthetic capacity associated with enhanced biosynthesis of UV absorbing compounds. This study shows that the biosynthesis of the UV-absorbing compound (RA) represents an effective mechanism to reduce the photoinhibitory and photooxidative damage caused by high UV stress.
\end{abstract}

Keywords: UV-B stress; photosynthetic performance; UV-B screening compounds; basil; tissue culture

\section{Introduction}

High ultraviolet B (UV-B wavelengths 280-315 nm) irradiation induces a variety of morphological responses in plants [1,2] and damaging effects on photosynthetic organisms. Damage to DNA, proteins, membranes, chloroplasts, massive generation of reactive oxygen species (ROS) can further lead to impairment of photosynthetic apparatus and induce programmed cell death (PCD), and ultimately the death of the photosynthetic organism [3-5].

Plants have evolved several mechanisms to cope with the detrimental effects of UV$B$ radiation including filtering UV radiation, repairing UV-induced DNA damage, and scavenging ROS [6,7]. The most common and powerful protective mechanism against UV-B irradiation is the biosynthesis of UV-absorbing compounds, mainly phenolic compounds, hydroxycinnamate esters, and flavonoids which alleviate the harmful effects of UV-B. These compounds act as UV-screens when they accumulate in the chloroplast mesophilic cells and vacuoles of epidermal cells [1]. In addition to their key role as filtering compounds, 
phenols are also known to have complement-independent effects such as scavenging of oxygen free radicals to control the deleterious levels of ROS [8]. Under detrimental environmental stress such as high doses of UVB, the performance of the photosynthetic apparatus of plants can be disrupted [9]. For the evaluation of plants' physiological status under stressful conditions, chlorophyll $a$ fluorescence (ChlF) is a fast and reliable indicator of photosynthetic capacity and plant stress level. With this type of measurement, without destroying the tested sample, scientists are able to get information on the efficiency of the photosynthetic process $[10,11]$.

The Lamiaceae family, one of the most important and widespread medicinal aromatic plant families, contains about 236 genera and 7136 species. Some of the largest genera in this family are Stachys (300), Plectranthus (300), Salvia (900), Scutellaria (360), Teucrium (250), Thymus (220), Hyptis (280), Nepeta (200), and Vitex (250) [12]. The phenolic compounds in this family have different medicinal properties such as antioxidant [13,14], anticancer [15], antifungal [16], and antimicrobial [17] activity and have been long considered as a source of valuable natural substances for health care.

One of the main member species of the Lamiaceae family is basil (Ocimum basilicum L). This species can accumulate high levels of different phenolics, such as flavonoids, phenolic terpenes, and phenolic acids, mainly rosmarinic acid (RA; R-O-caffeoyl-3-4dihydroxyphenyllactic acid), an ester of caffeic acid, and 3-4 dihydroxy phenyllactic acid with biological activities including antiviral, antibacterial, antioxidant, and antiinflammatory activity $[18,19]$. Basil accessions showed variability at the DNA level (genotypes) [20], essential oil composition (chemotypes) [21], and morphology (morphotypes) [22,23]. Basil plants are able to grow in several regions all over the world [23]. There has been little research on intra-specific photosynthetic and metabolic differences in UV-B tolerance across ecotypes from different geographical areas. Therefore, to gain a better understanding of UV-B stress-tolerant responses, this study evaluated the protection responses to high UV-B radiation in nine $O$. basilicum accessions with different geographic origins. The screening of different plant genotypes to highlight responses to abiotic stress conditions or to verify phytochemicals production under different growth conditions can be carried out with various strategies including in vitro plant tissue cultures $[8,24]$. This technique has many advantages such as standardized methods and complete control of environmental factors. However, only plants grown in vivo permit the detection of stress symptoms. In this paper, we adopt a culture system in vitro-vivo [25] where the autotrophic growth of seedlings could allow the advantages of both approaches to be combined.

\section{Materials and Methods}

\subsection{Plant Material, In Vitro Growth Conditions}

Seeds of nine different ecotypes of Ocinum basilicum L. var. basilicum from the north to the south of the world were obtained from GBIS/I (Genebank Information System of the IPK Gatersleben, Germany) (Table 1). Seeds were soaked for $10 \mathrm{~min}$ in a solution of $20 \%$ sodium hypochlorite plus $0.01 \%$ Triton X-I00 (Sigma Aldrich, Milano, Italy) to sterilize the surface efficiently, and then, they were rinsed four times with sterile water. The seeds were plated on Murashige and Skoog [26] media with 3\% $(w / v)$ sucrose and 1.2\% $(w / v)$ Agar $^{\mathrm{TM}}$ (Sigma Aldrich, Milano, Italy), $\mathrm{pH}$ 5.7. In order to promote the synchronization of seed germination, the seeds were placed at $4{ }^{\circ} \mathrm{C}$ for $48 \mathrm{~h}$. Then the sown plates were transferred to a growth chamber settled with a temperature of $22{ }^{\circ} \mathrm{C}$, under $16 \mathrm{~h}\left(100 \mu \mathrm{mol}^{-1} \mathrm{~m}^{-2} \mathrm{~s}^{-1}\right)$ of light and $8 \mathrm{~h}$ of darkness for germination.

\subsection{Culture System}

Five-day-old seedlings were transferred and grown in a previously developed "in vitrovivo system" $[25,27]$. Briefly, basil seedlings were placed in Falcon ${ }^{\mathrm{TM}}$ (BD Bioscience, Belgium) tubes including $60 \mathrm{~mL}$ of agarized MS medium without growth regulators and sucrose. The tubes were appropriately modified by making two holes on the cylindrical surface that enabled the growth of two plantlets with the root system growing into an 
in-vitro medium and the aerial part "in air" to guarantee the effectiveness of UV-B radiation treatment. After transfer, the stems of the plantlets were sealed with sterile plasticine, and the falcon containers were then placed horizontally on the longer side.

Table 1. O. basilicum accessions (ecotypes) and their geographical distributions.

\begin{tabular}{cccc}
\hline O. basilicum Stock No. & Country of Origin (Location) & Coordinate & $\begin{array}{c}\text { Elevation } \\
\text { above the Sea Level (m) }\end{array}$ \\
\hline OCI142 & Maldives & N4 E73 & 8 \\
OCI148 & Maldives & N4 E73 & 8 \\
OCI149 & Maldives & N4 E73 & 8 \\
OCI30 & Argentina & N2 W75 & 1559 \\
OCI102 & Romania & N44 E26 & 83 \\
OCI126 & Georgia & N39 E116 W3 & 49 \\
OCI370 & Spain & N8 0-1E & 665 \\
OCI118 & Togo & N21 W80 & 481 \\
OCI160 & Cuba & & 41 \\
\hline
\end{tabular}

The seedlings were grown in Falcon containers at a constant temperature of $22{ }^{\circ} \mathrm{C}$ for two weeks under light $\left(100 \mu \mathrm{mol}^{-1} \mathrm{~m}^{-2} \mathrm{~s}^{-1}\right.$ provided by L 36W/76 "Cool White" fluorescent tubes, Osram, Munich, Germany). The plants within the growth chamber were arranged randomly on one shelf.

\subsection{UV-B Exposure}

The UV-B- treatment was carried out in the dark. Plants were positioned in a shielded cabinet equipped with UV-B lamps (UV-B GL20 SE, Sankyo Denki, Tokyo, Japan), whose emission spectrum ranged $\lambda$ from 280 to $400 \mathrm{~nm}$, resulting in a maximum peak at $325 \mathrm{~nm}$. Then, the plants were subjected to a high UV-B dose of $68 \mathrm{~kJ} \mathrm{~m}^{-2} \mathrm{~d}^{-1}$. This was achieved

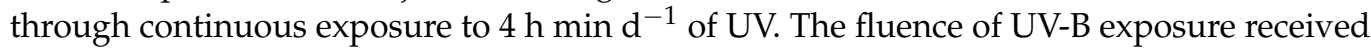
by the plants during the experiment was measured using a Light Sensor Reader equipped with a UV Sensor (Field Scout ${ }^{\mathrm{TM}}$ Spectrum Technologies, Inc. Plainfield, IL, USA). The control plants were maintained under cool white light at $100 \mu \mathrm{mol} \mathrm{m}^{-2} \mathrm{~s}^{-1}$ provided by fluorescence tubes. After UV-B treatment, the plants were returned to control conditions (constant temperature of $22{ }^{\circ} \mathrm{C}, 16 \mathrm{~h}$ photoperiod with $100 \mu \mathrm{mol}^{-1} \mathrm{~m}^{-2} \mathrm{~s}^{-1}$ white light, $65 \% \mathrm{RH})$ for another $72 \mathrm{~h}$.

\subsection{Determination of Rosmarinic Acid}

The concentration of rosmarinic acid in sweet basil was performed according to Maggini et al. [28] and Kiferle et al. [24] protocols. Briefly, $300 \mathrm{mg}$ FW of frozen tissues were ground in a mortar with $5 \mathrm{~mL}$ of extraction solvent (EtOH: $\mathrm{H}_{2} \mathrm{O}: \mathrm{HCl}$ 80:19:1 v/v) and sieved into plastic tubes. Samples were sonicated for $1 \mathrm{~h}$ and to prevent the heating of the sample, the sonication was carried out on ice. The samples were incubated overnight at $-20{ }^{\circ} \mathrm{C}$. Then, the samples were centrifuged at $3000 \mathrm{rpm}$ for $5 \mathrm{~min}$ and the collected supernatants were transferred into fresh tubes. The pellet was extracted with $5 \mathrm{~mL}$ of fresh solvent and sonicated again, then it was incubated overnight at $-20{ }^{\circ} \mathrm{C}$. After centrifugation, the two supernatants were combined for analysis. Chromafil ${ }^{\circledR}$ syringe filters $(0.45 \mu \mathrm{m}$ cellulose mixed esters membrane; 25 mm diameter; Macherey-Nagel, Düren, Germany) were used for the filtration of all extracts prior to HPLC separations.

HPLC grade solvents were used for the analyses and the HPLC equipment (Jasco, Tokyo, Japan) included a PU-2089 four-solvent low-pressure gradient pump and a MD4010 diode array detector. Analyses were performed using a Macherey-Nagel C18 250/4.6 Nucleodur ${ }^{\circledR} 100-5$ Isis column equipped with a guard column, at a flow rate of $1 \mathrm{~mL} \mathrm{~min}^{-1}$. Acetonitrile (solvent $\mathrm{A}$ ) and aqueous $0.1 \%$ phosphoric acid (solvent $\mathrm{B}$ ) were used for elution, with the following gradient: 0-0.4 min, A 5\%; 0.4-10 min, A 5-50\%; 10-15 min, A 50-95\%; 15-17 min, A 95\%; 17-19 min, A 95-5\%; followed by 5 min equilibration (A 5\%). 
The detection wavelength range was $220-450 \mathrm{~nm}$. The analyses were performed at room temperature $\left(23-24^{\circ} \mathrm{C}\right)$, using an injection volume of $20 \mu \mathrm{L}$.

Rosmarinic acid was identified by comparing the retention times and absorption spectra obtained at maximum peak with those of analytically pure standard (Phytolab $\mathrm{GmbH}$, Westenbergsgreuth, Germany).

\subsection{Chlorophyll a Fluorescence}

Measurements of chlorophyll $a$ fluorescence were conducted using a portable HandyPEA chl fluorometer (Hansatech, Kings Lynn, UK). The leaves were first dark acclimated for $30 \mathrm{~min}$ at room temperature by fixing leaf clips (Hansatech, Kings Lynn, UK). Then, chlorophyll $a$ fluorescence transients were recorded by illuminating the leaves with a beam of saturating light $\left(3000 \mu \mathrm{mol} \mathrm{m} \mathrm{m}^{-2} \mathrm{~s}^{-1}\right)$ of $650 \mathrm{~nm}$ peak wavelength, obtained from three light-emitting diodes focused on the leaf surface through the clips on a spot of $4 \mathrm{~mm}$ diameter circle. Leaf fluorescence detection was measured by a fast response PIN photodiode with an RG9 long-pass filter (Hansatech, Kings Lynn, UK, technical manual). JIP analysis was performed to determine the following parameters: (i) Efficiency: maximum quantum yield of primary PSII photochemistry (Fv/Fm); (ii) Specific fluxes per reaction center (RC): the absorption/antenna size (ABS/RC), maximum trapping $\left(\mathrm{TR}_{0} / \mathrm{RC}\right)$, electrons transferred $\left(\mathrm{ET}_{0} / \mathrm{RC}\right)$, and dissipated $\left(\mathrm{DI}_{0} / \mathrm{RC}\right.$ ) per active PSII; (iii) Phenomenological energy fluxes: the absorption $\left(\mathrm{ABS} / \mathrm{CS}_{0}\right)$, maximum trapping $\left(\mathrm{TR}_{0} / \mathrm{CS}_{0}\right)$, electron fluxes transferred $\left(\mathrm{ET}_{0} / \mathrm{CS}_{0}\right)$, dissipation $\left(\mathrm{DI}_{0} / \mathrm{CS}_{0}\right)$ and active reaction centers $\left(\mathrm{RC} / \mathrm{CS}_{0}\right)$ per cross section $\left(\mathrm{CS}_{0}\right)$.

\subsection{Statistical Analysis}

The whole experiment counting the treatment and control was independently repeated three times. The chlorophyll $a$ fluorescence measurement was performed immediately after UV-B exposure ( $0 \mathrm{~h}$ ), and after 24 and $48 \mathrm{~h}$ of recovery time. Rosmarinic acid content was determined at the end of the recovery time $(48 \mathrm{~h})$. Statistical analyses were performed with PRISM 6 software (GraphPad Software, San Diego, CA, USA). All data were expressed as means $(n=5) \pm S E$ of the number of replicates. Through the two-way ANOVA statistical significance effect of UV-B treatments was examined. Differences between various ecotypes treated with high UV-B doses were determined by using the Tukey posttest $(p<0.05)$.

\section{Results}

\subsection{Visual Effects of UV-B Exposures}

Nine $O$. basilicum ecotypes accessions originating from different geographical locations were selected to study plant responses to UV radiation. These basil accessions were grown in a previously described "in vitro-vivo system" $[25,27,29]$ and were UV-B irradiated using a high UV-B dose in order to depict the overall effects of UV radiation on the magnitude of UV-protection of the photosynthetic machinery using parameters derived from chlorophyll a fluorescence measurements and the accumulation of UV screening phenolic compounds like rosmarinic acid.

The basil plants were irradiated with a high UV-B dose $\left(68 \mathrm{~kJ} \mathrm{~m}^{-2} \mathrm{~d}^{-1}\right)$ by continuous exposure to $4 \mathrm{~h} \mathrm{~min} \mathrm{~d}^{-1}$ of $\mathrm{UV}$, already reported to cause stress on $\mathrm{O}$. basilicum plantlets [25,27]. After the UV-B exposure, plants were placed in a light regime along with the already present control plants for up to $48 \mathrm{~h}$ (recovery period). Pronounced leaf-browning, necrosis/wilting, and leaf curling symptoms were observed after $48 \mathrm{~h}$ of UV-treatment in six accessions (i.e., OCI149, OCI102, OCI118, OCI142, OCI148, OCI126) (Figure 1). On the other hand, glossy leaves and less severe leaf-browning features were observed in OCI370 and OCI30, and noticeably, OCI160 manifested the slightest signs of UV-stress injuries compared to all other ecotypes as shown in Figure 1. 


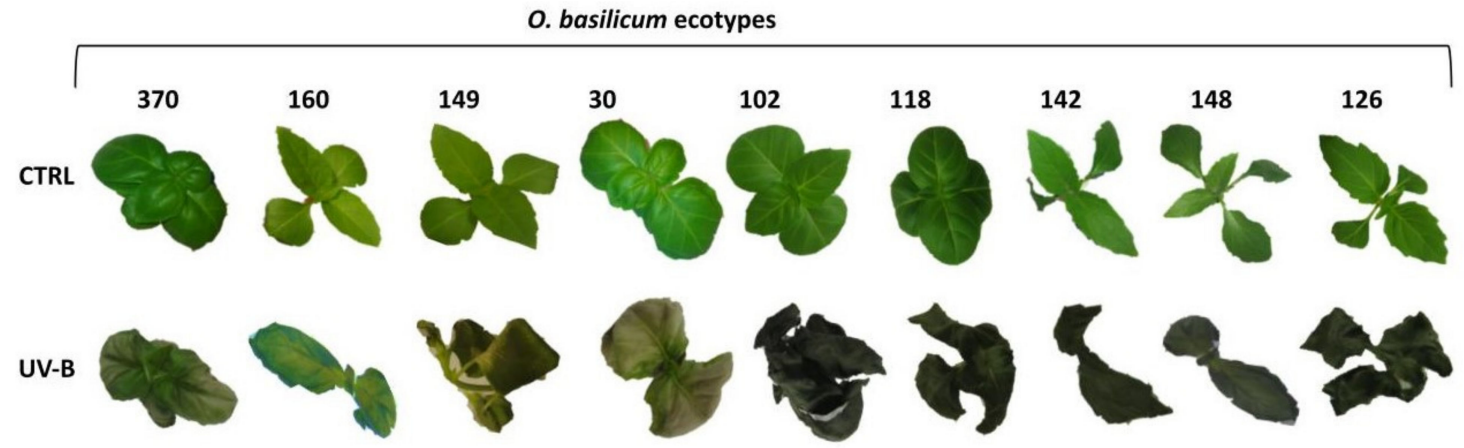

Figure 1. Appearance of nine different $O$. basilicum ecotypes over $48 \mathrm{~h}$, after UV-B exposure $\left(68 \mathrm{~kJ} \mathrm{~m}^{-2}\right.$ day $\left.^{-1}\right)$ and control (Ctrl) condition (not UV-B exposed).

\subsection{Chlorophyll a Fluorescence}

The response of different $O$. basilicum accessions subjected to high UV-B dose was evaluated at the level of photosynthetic machinery by measuring the fast chlorophyll $a$ fluorescence transient at $0,4,24$, and $48 \mathrm{~h}$ from the beginning of UV-B exposure. The calculated functional parameters linked to the health status of the plantlets, are the specific (per reaction center, RC) and phenomenological (per cross section of the sample, CS) energy fluxes for absorption (ABS), trapping (TR), electron transport (ET), and dissipation (DI) as well as the maximum quantum yield of primary PSII photochemistry (Fv/Fm).

The exposure of basil leaves to high UV-B doses led to a general decrease of the maximum yield of PSII (Fv/Fm ratio) after $4 \mathrm{~h}$ (at the end of UV-B light exposure) and it gradually decreased over the $48 \mathrm{~h}$ recovery period in almost all basil accessions tested (Table 2). On the other hand, the OCI160 ecotype was the least affected by UV-B light stress and showed the highest $\mathrm{Fv} / \mathrm{Fm}$ value at $48 \mathrm{~h}$ during recovery compared to others (Figure 2).

Table 2. Effect of UV-B exposure $\left(68 \mathrm{~kJ} \mathrm{~m}^{-2}\right.$ day $\left.^{-1}\right)$ in nine different sweet basil ecotypes at different recovery times $(0$, $4 \mathrm{~h}, 24$, and 48) on selected chlorophyll $a$ fluorescence parameters. Analysis of variance was used for comparisons. Means within each column (O. basilicum ecotypes) and within each chlorophyll $a$ fluorescence parameter assessed followed by different letters are significantly different $(p<0.05$; Tukey's multiple range test, $\mathrm{n}>5$ ).

\begin{tabular}{|c|c|c|c|c|c|c|c|c|c|c|}
\hline \multicolumn{11}{|c|}{ O. basilicum Ecotypes } \\
\hline & & OCI142 & OCI148 & OCI149 & OCI30 & OCI160 & ОСI370 & OCI102 & OCI118 & OCI126A \\
\hline \multirow{4}{*}{ ABS/RC } & $0 \mathrm{~h}$ & $3.32 \mathrm{a}$ & $3.28 \mathrm{a}$ & $2.77 \mathrm{a}$ & $3.24 \mathrm{a}$ & $3.41 \mathrm{a}$ & $3.47 \mathrm{a}$ & $3.25 \mathrm{a}$ & $3.36 \mathrm{a}$ & $3.29 \mathrm{a}$ \\
\hline & $4 \mathrm{~h}$ & $4.30 \mathrm{~b}$ & $4.41 \mathrm{~b}$ & $5.58 \mathrm{~b}$ & $4.54 \mathrm{~b}$ & $3.54 \mathrm{a}$ & $4.50 \mathrm{~b}$ & $4.60 \mathrm{~b}$ & $5.51 \mathrm{~b}$ & $4.98 \mathrm{~b}$ \\
\hline & $24 \mathrm{~h}$ & $7.2 \mathrm{c}$ & $4.07 \mathrm{~b}$ & $13.93 \mathrm{c}$ & $6.36 \mathrm{~b}$ & $4.25 \mathrm{~b}$ & $5.29 \mathrm{cb}$ & $14.45 \mathrm{c}$ & $4.63 c$ & $10.61 \mathrm{c}$ \\
\hline & $48 \mathrm{~h}$ & $20.04 \mathrm{~d}$ & 17.32 c & $19.16 \mathrm{~d}$ & $12.20 \mathrm{~d}$ & $4.80 \mathrm{c}$ & $5.98 \mathrm{c}$ & $17.20 \mathrm{~d}$ & $13.18 \mathrm{~d}$ & $16.57 \mathrm{~d}$ \\
\hline \multirow{4}{*}{ TRo/RC } & $0 \mathrm{~h}$ & $2.73 \mathrm{a}$ & $2.81 \mathrm{a}$ & $2.92 \mathrm{a}$ & $2.91 \mathrm{a}$ & $2.87 \mathrm{a}$ & $2.83 \mathrm{a}$ & $2.85 \mathrm{a}$ & $2.74 \mathrm{a}$ & $2.71 \mathrm{a}$ \\
\hline & $4 \mathrm{~h}$ & $2.49 \mathrm{~b}$ & $2.45 \mathrm{~b}$ & $2.45 \mathrm{~b}$ & $2.76 \mathrm{ab}$ & $2.72 \mathrm{a}$ & $2.80 \mathrm{a}$ & $2.68 \mathrm{~b}$ & $2.44 \mathrm{~b}$ & $2.34 \mathrm{~b}$ \\
\hline & $24 \mathrm{~h}$ & $2.11 \mathrm{~b}$ & $2.11 \mathrm{c}$ & $2.03 \mathrm{c}$ & $2.42 \mathrm{~b}$ & $2.64 \mathrm{~b}$ & $2.42 \mathrm{~b}$ & $2.33 \mathrm{~b}$ & $2.01 \mathrm{c}$ & $1.84 \mathrm{c}$ \\
\hline & $48 \mathrm{~h}$ & $1.83 \mathrm{c}$ & $1.91 \mathrm{~d}$ & $1.55 \mathrm{~d}$ & $1.79 \mathrm{c}$ & $2.41 \mathrm{c}$ & $2.12 \mathrm{c}$ & $1.60 \mathrm{c}$ & $1.69 \mathrm{~d}$ & $1.67 \mathrm{~d}$ \\
\hline \multirow{4}{*}{ ETo/RC } & $0 \mathrm{~h}$ & $1.59 \mathrm{a}$ & $1.38 \mathrm{a}$ & $1.56 \mathrm{a}$ & $1.55 \mathrm{a}$ & $1.48 \mathrm{a}$ & $1.47 \mathrm{a}$ & $1.38 \mathrm{a}$ & $1.56 \mathrm{a}$ & $1.43 \mathrm{a}$ \\
\hline & $4 \mathrm{~h}$ & $1.48 \mathrm{a}$ & $1.22 \mathrm{~b}$ & $1.21 \mathrm{~b}$ & $1.13 \mathrm{~b}$ & $1.40 \mathrm{a}$ & $1.39 \mathrm{a}$ & $1.22 \mathrm{~b}$ & $1.21 \mathrm{~b}$ & $0.86 \mathrm{~b}$ \\
\hline & $24 \mathrm{~h}$ & $1.22 \mathrm{~b}$ & $1.07 \mathrm{c}$ & $0.91 \mathrm{c}$ & $0.94 \mathrm{c}$ & $1.29 \mathrm{~b}$ & $1.01 \mathrm{~b}$ & $1.07 \mathrm{c}$ & $0.91 \mathrm{c}$ & $0.81 \mathrm{~b}$ \\
\hline & $48 \mathrm{~h}$ & $0.40 \mathrm{c}$ & $0.38 \mathrm{~d}$ & $0.62 \mathrm{c}$ & $0.68 c$ & $1.07 \mathrm{c}$ & $0.79 \mathrm{c}$ & $0.38 \mathrm{~d}$ & $0.62 \mathrm{c}$ & $0.59 \mathrm{c}$ \\
\hline \multirow{4}{*}{ DIo/RC } & $0 \mathrm{~h}$ & $0.59 \mathrm{a}$ & $0.54 \mathrm{a}$ & $0.50 \mathrm{a}$ & $0.59 \mathrm{a}$ & $0.57 \mathrm{a}$ & $0.55 \mathrm{a}$ & $0.60 \mathrm{a}$ & $0.52 \mathrm{a}$ & $0.58 \mathrm{a}$ \\
\hline & $4 \mathrm{~h}$ & $1.81 \mathrm{~b}$ & $1.96 \mathrm{~b}$ & $3.55 \mathrm{~b}$ & $2.08 \mathrm{~b}$ & $1.73 \mathrm{~b}$ & $2.08 \mathrm{~b}$ & $1.92 \mathrm{~b}$ & $1.06 \mathrm{~b}$ & $2.48 \mathrm{~b}$ \\
\hline & $24 \mathrm{~h}$ & $5.37 c$ & $3.17 \mathrm{c}$ & $3.67 \mathrm{~b}$ & $1.93 \mathrm{~b}$ & $1.82 \mathrm{~b}$ & $2.83 \mathrm{~b}$ & $12.11 \mathrm{c}$ & $1.57 \mathrm{c}$ & $8.94 \mathrm{c}$ \\
\hline & $48 \mathrm{~h}$ & $17.93 \mathrm{~b}$ & $15.53 \mathrm{~d}$ & $19.01 \mathrm{~b}$ & $12.40 \mathrm{C}$ & $2.4 \mathrm{c}$ & $3.97 \mathrm{c}$ & $20.74 \mathrm{c}$ & $16.49 \mathrm{c}$ & $18.43 \mathrm{c}$ \\
\hline \multirow{4}{*}{$\mathrm{RC} \mathrm{CS}_{0}$} & $0 \mathrm{~h}$ & $309.49 \mathrm{a}$ & $338.16 \mathrm{a}$ & $333.60 \mathrm{a}$ & $322.97 \mathrm{a}$ & $337.83 \mathrm{a}$ & $318.81 \mathrm{a}$ & $314.83 \mathrm{a}$ & $361.82 \mathrm{a}$ & $330.61 \mathrm{a}$ \\
\hline & $4 \mathrm{~h}$ & $317.62 \mathrm{a}$ & $282.03 \mathrm{~b}$ & $303.69 \mathrm{a}$ & $258.04 \mathrm{~b}$ & $299.57 \mathrm{a}$ & $270.30 \mathrm{a}$ & $262.83 \mathrm{~b}$ & $246.09 \mathrm{~b}$ & $181.67 \mathrm{~b}$ \\
\hline & $24 \mathrm{~h}$ & $230.80 \mathrm{~b}$ & $277.51 b$ & $172.92 \mathrm{~b}$ & $242.12 \mathrm{~b}$ & $255.90 \mathrm{~b}$ & $201.19 \mathrm{~b}$ & $187.22 \mathrm{c}$ & $150.25 \mathrm{c}$ & $155.27 \mathrm{~b}$ \\
\hline & $48 \mathrm{~h}$ & $41.45 \mathrm{c}$ & $43.58 \mathrm{c}$ & $49.89 \mathrm{c}$ & $67.11 \mathrm{c}$ & $225.90 \mathrm{c}$ & $163.07 \mathrm{c}$ & $35.86 \mathrm{~d}$ & $68.43 \mathrm{~d}$ & $76.04 \mathrm{c}$ \\
\hline
\end{tabular}




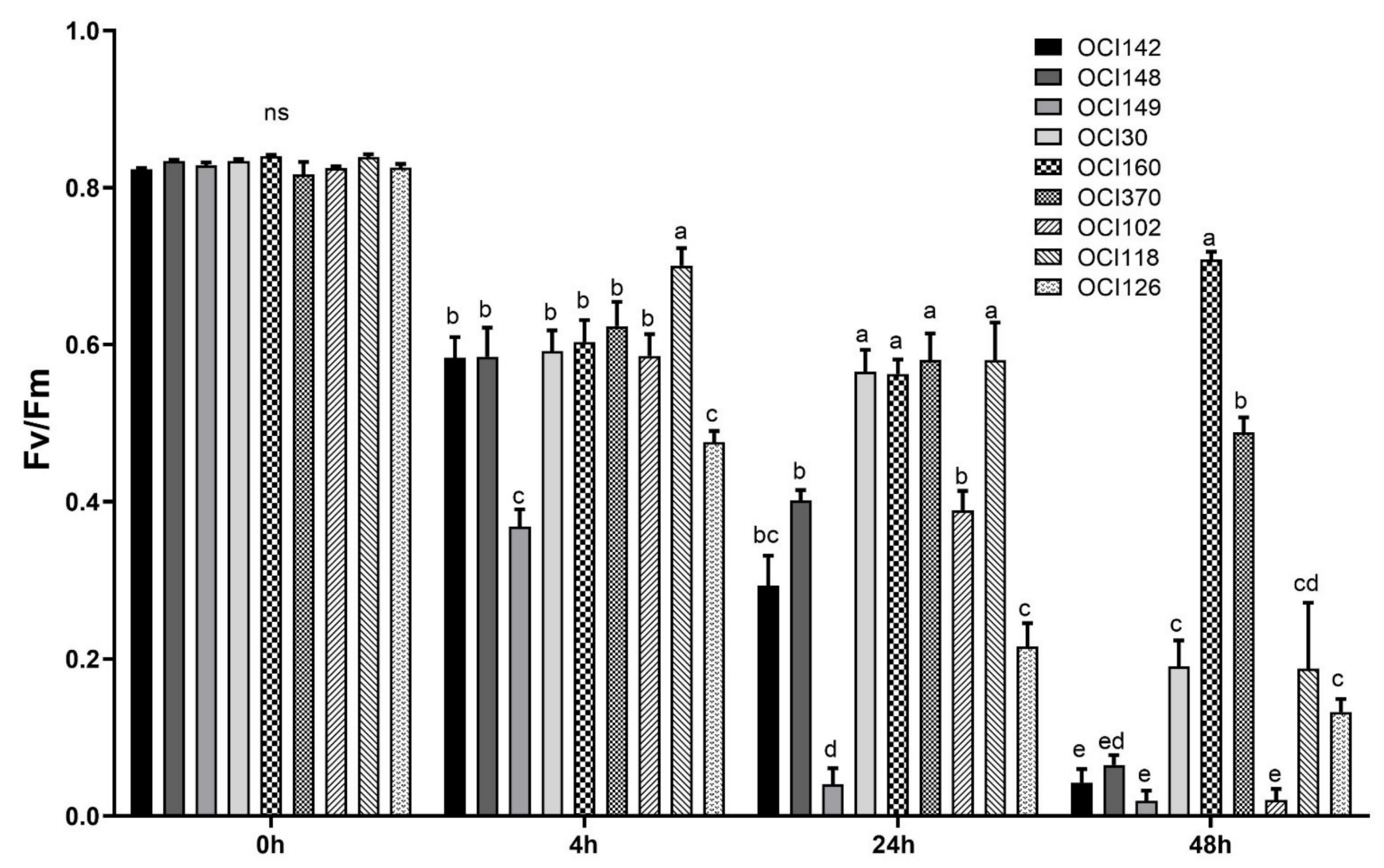

Figure 2. Time course of maximum quantum efficiency of photosystem II, (Fv/Fm) measured in leaves of nine different sweet basil ecotypes exposed to UV-B light $\left(68 \mathrm{~kJ} \mathrm{~m}^{-2}\right.$ day $\left.{ }^{-1}\right)$ or not exposed $(0 \mathrm{~h})$. The measurements were carried out at 0 , $4 \mathrm{~h}, 24 \mathrm{~h}$, and $48 \mathrm{~h}$ after the end of the UV-B exposure. Data are shown as means with at least five independent biological replicates and error bars indicate standard error. Data were subjected to analysis of variance and differences were analyzed by Tukey's posttest. Different letters denote significant differences at $p<0.05$ (ns: not significant).

The parameters related to the specific energy fluxes (ABS/RC, $\mathrm{TR}_{0} / \mathrm{RC}, \mathrm{ET}_{0} / \mathrm{RC}$, and $\mathrm{DI}_{0} / \mathrm{RC}$ ) and the phenomenological energy fluxes through the cross section of the sample $\left(\mathrm{CS}_{0}\right)$, such as percentage of active reaction centers $\left(\mathrm{RC} / \mathrm{CS}_{0}\right)$ displayed alterations due to UV-B radiation treatment, as compared to the not UV-B treated ones $(0 \mathrm{~h})$ (Table 2). $\mathrm{TR}_{0} / \mathrm{RC}, \mathrm{ET}_{0} / \mathrm{RC}$, and $\mathrm{RC} / \mathrm{CS}_{0}$ significantly declined, whereas $\mathrm{ABS} / \mathrm{CS}_{0}$ and $\mathrm{DI}_{0} / \mathrm{CS}_{0}$ significantly increased with high UV-B radiation in all ecotypes. The lowest decreases in $\mathrm{TR}_{0} / \mathrm{RC}, \mathrm{ET}_{0} / \mathrm{RC}$, and $\mathrm{RC} / \mathrm{CS}_{0}$ and the lowest increases in $\mathrm{ABS} / \mathrm{CS}_{0}$ and $\mathrm{DI}_{0} / \mathrm{CS}_{0}$ were found in OCI160 plants (Table 2).

UV-B radiation caused significant changes in the phenomenological energy fluxes through the cross section of the sample $\left(\mathrm{CS}_{0}\right)$ parameters $\left(\mathrm{ABS} / \mathrm{CS}_{0}, \mathrm{TR}_{0} / \mathrm{CS}_{0}, \mathrm{ET}_{0} / \mathrm{CS}_{0}\right.$, and $\mathrm{DI}_{0} / \mathrm{CS}_{0}$ ) (Figure 3).

UV-B was found to increase the values of absorption (ABS)/CS $\mathrm{C}_{0}$ over time in all ecotypes (Figure 3A, Table S1). ABS/CS increased after 48 h of UV-B treatment in OCI160 plants but UV-B radiation caused a less noticeable increase, compared to the others accessions (Figure 3A).

Trapped energy per cross-section (TRo/CS $)$ was lower in all UV-B treated ecotypes (Table S1) than in the control plants. A higher value (480 and 334) at the end of the recovery period ( $48 \mathrm{~h}$ ) was found in OCI160 and OCI30 plants, respectively, exposed to UV-B light (Figure 3B). 
A

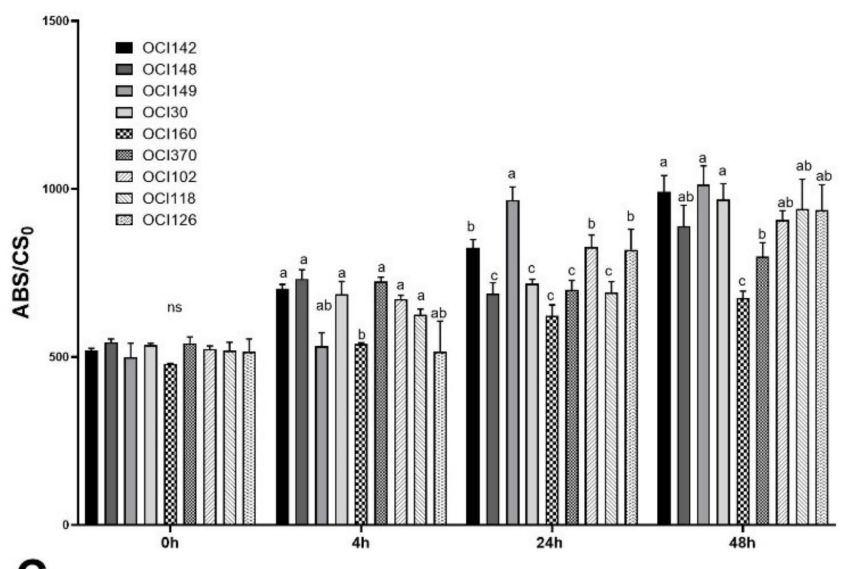

C

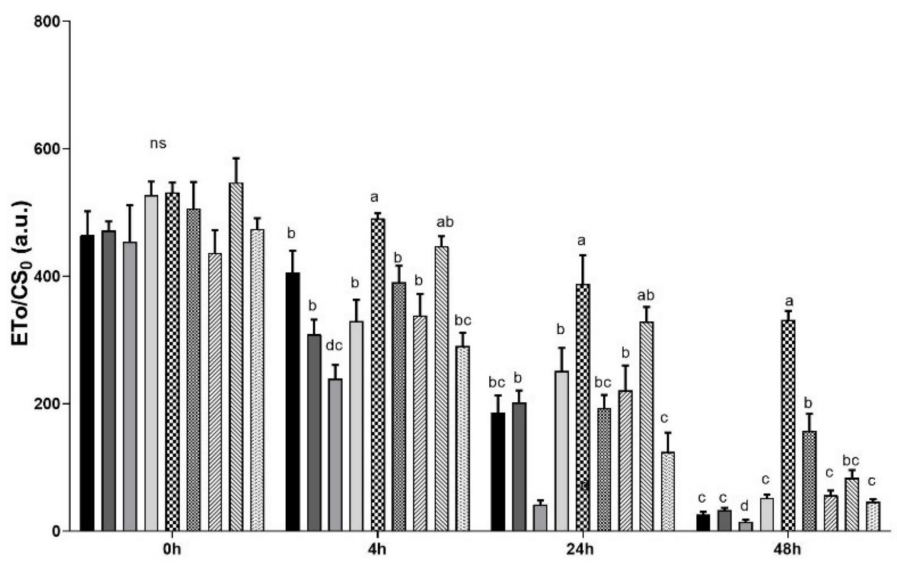

B
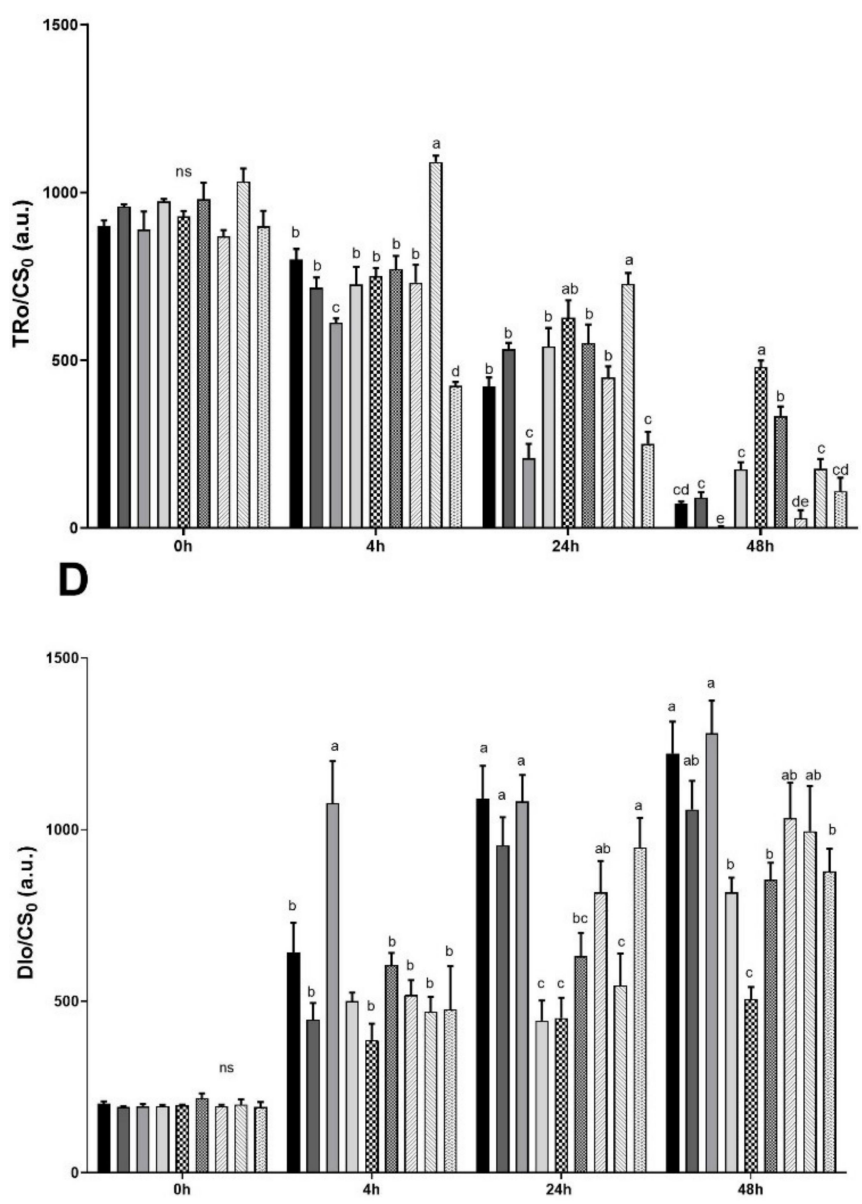

Figure 3. Time course of chlorophyll $a$ fluorescence parameters measured in leaves of nine different sweet basil ecotypes exposed to UV-B light $\left(68 \mathrm{~kJ} \mathrm{~m}^{-2} \mathrm{day}^{-1}\right.$ ) or not exposed (ctrl). (A) Absorption flux per cross section, ABS/CS ; (B) Trapped energy per cross section, $\mathrm{TRo} / \mathrm{CS}_{0} ;(\mathbf{C})$ Electron transport flux per cross section, $\mathrm{ETo} / \mathrm{CS}_{0} ;(\mathrm{D})$ Dissipation energy per cross section, DIo/ $\mathrm{CS}_{0}$. Data are shown as means with at least five independent biological replicates. The measurements were carried out at $0,4 \mathrm{~h}, 24 \mathrm{~h}$, and $48 \mathrm{~h}$ after the end of the UV-B exposure. Values are means with standard errors $(\mathrm{n}=5)$ and error bars indicate standard error. Data were subjected to the analysis of variance and differences were analyzed by Tukey's posttest. Different letters within the time denote significant differences at $p<0.05$.

Similarly, the electron transport flux per cross-section $\left(\mathrm{ETo} / \mathrm{CS}_{0}\right)$ gradually decreased in all ecotypes after high UV-B radiation before drastically dropping after $48 \mathrm{~h}$ of UV-B exposure, except for OCI160 exhibiting the highest value at $48 \mathrm{~h}$, followed by OCI30 plants. $\mathrm{ETo} / \mathrm{CS}_{0}$ was higher in OCI160 at the end of the experiment, approximately 331, while in all other species the values ranged from 14 to 157 (Table S1, Figure 3C).

The energy dissipated per reaction center $\left(\mathrm{DIo} / \mathrm{CS}_{0}\right)$ in all accessions increased after UV-B exposure (Table S1). However, in OCI160 plants, DIo/ $\mathrm{CS}_{0}$ increased less during the 24 and $48 \mathrm{~h}$ recovery periods, showing the lowest level compared to the other accessions within the same timing (Figure 3D).

\subsection{Effect of High UV-B Light Exposure on the Rosmarinic acid (RA) Content}

The concentration of RA varied significantly $(p<0.05)$ among basil accessions grown under high UV-B light after $48 \mathrm{~h}$ (Figure 4). 


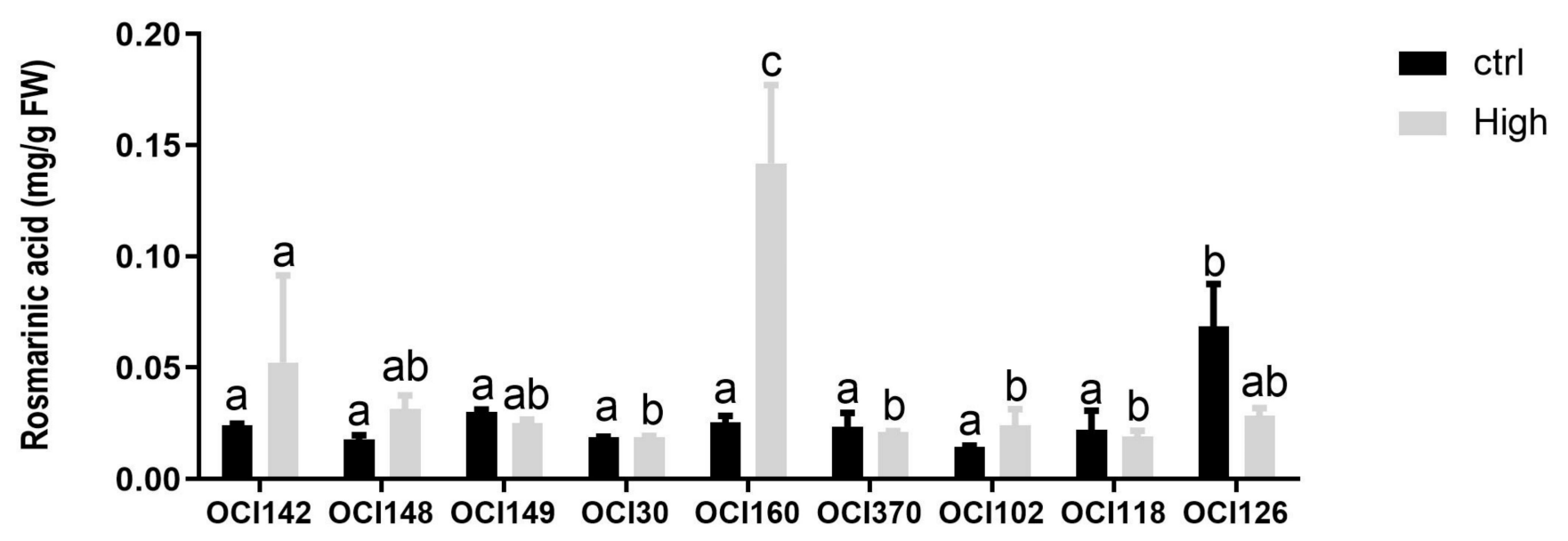

Figure 4. Time course of changes in rosmarinic acid content in leaves of nine different sweet basil ecotypes exposed to UV-B light $\left(68 \mathrm{~kJ} \mathrm{~m}^{-2} \mathrm{day}^{-1}\right)$ or not exposed (ctrl). Data are shown as mean with at least five independent biological replicates. The measurements were carried out at $48 \mathrm{~h}$ from the beginning of the exposure. Data were subjected to analysis of variance and differences between ecotypes were analyzed by Tukey's multiple comparisons test. Different letters denote significant differences at $p<0.05$.

The accumulation of RA increased significantly by UV-B light treatment in OCI142, OCI148, OCI30, OCI160, and OCI102, with the highest concentration measured in OCI160 leaves. In contrast, UV-B exposure reduced the accumulation of RA in OCI102, while the other accessions did not show changes compared to untreated $(0 \mathrm{~h})$ plants.

\section{Discussion}

This study used an "in vitro-in vivo system" in a closed-type plant production system for plant growth in a controlled environment that allowed screening and selection of the highest UV-B tolerant ecotypes of O. basilicum by comparing, on the one hand, the biosynthesis/accumulation of a UV-absorbing compound like RA as a protective mechanism to avoid the harmful effects of UV radiation [1] and, on the other side, the effects on the efficiency of PSII photochemistry as the main target of UV-B light-induced inhibition of the photosynthetic machinery [30]. The use of an "in vitro-in vivo system" in a closed-type plant production system, first developed by Srivastava et al. [29] and then modified by Mosadegh et al. [25] allowed the growth of plantlets with root systems growing into the "in-vitro" medium and the aerial part "in the air" to guarantee the effectiveness of UV-B treatment as well as the proper manipulation of UV-B radiation by turning on and off the UV-B lamps. In this screening procedure for ecotypes' UV-B tolerance evaluation, a two-stage specific strategy was applied.

First, the $O$. basilicum ecotypes were grown under control conditions for three weeks and then subjected to UV-B radiation for $4 \mathrm{~h}$ reaching a fluence rate of $68 \mathrm{~kJ} \mathrm{~m}^{-2} \mathrm{~d}^{-1}$ (high UV-B dose), to depict the photosynthetically mediated effects of UV-B radiation using parameters derived from chlorophyll $a$ fluorescence measurement, and the changes of UV-inducible RA accumulation in leaf tissue.

The stress-induced damage and adverse effects of high UV-B radiation on photosynthetic activity (mainly related to PSII performance) has been broadly accepted [27,30-32] and chlorophyll $a$ fluorescence is used as a non-invasive measurement of PSII activity for rapid screening of photosynthesis that gives high-resolution information regarding a plant's status and thus very useful to analyse the functionality of leaves exposed to several stressful conditions [33-39].

When basil leaves were exposed to high UV-B radiation a gradual decrease of the maximum yield of PSII (Fv/Fm ratio) after $4 \mathrm{~h}$ (at the end of UV-B light exposure) and gradually decreased over the $48 \mathrm{~h}$ recovery period in almost sweet basil accessions tested was observed (Table S1). On the other hand, the OCI160 ecotype was the least affected by 
UV-B light stress and showed the highest $\mathrm{Fv} / \mathrm{Fm}$ value at $48 \mathrm{~h}$ during recovery compared to others (Figure 2).

High UV-B irradiation gradually decreased the maximal photochemical activity of PSII (expressed as $\mathrm{Fv} / \mathrm{Fm}$ ), measured after dark adaptation in sweet basil ecotypes leaves after $4 \mathrm{~h}$, and this UV-B effect was more severe after $48 \mathrm{~h}$ from the beginning of the experiment (during recovery) in almost sweet basil accessions tested, indicating that these are the most sensitive ecotypes in which such high energy light causes inhibition of the photosynthetic machinery and severe signs of UV-stress injuries (Figure 1). High UV-B radiation causes a reduction in photosynthesis, associated with decreased fluorescence, parameter such as $\mathrm{Fv} / \mathrm{Fm}$, indicating injury to the photosystems in several plants [25,27,40-42]. In contrast, the UV-treated OCI160 ecotype was clearly much more resistant to high UV-B stress and showed the highest Fv/Fm value at $48 \mathrm{~h}$ during recovery (Figure 2) and less signs of UV-stress injuries compared to others (Figure 1). In different Arabidopsis accessions grown under high UV-B dose, higher Fv/Fm values were interpreted as a greater protective capability, i.e., increased UV-B tolerance [41].

The performance of the photosynthetic apparatus plays a key role in the physiological status and vitality of plants under environmental stress.

Chlorophyll $a$ fluorescence transient data were analyzed by using the JIP-test to quantify the physiological damage to photosynthetic machinery under high UV-B radiation in basil leaves $[39,43,44]$. In this study, the specific and phenomenological fluxes were significantly affected by UV-B radiation. Specific energy fluxes $\left(\mathrm{TR}_{0} / \mathrm{RC}, \mathrm{ET}_{0} / \mathrm{RC}\right)$ of all ecotypes decreased under UV-B treatment as compared to not treated ones, while $\mathrm{DI}_{0} / \mathrm{RC}$ and $\mathrm{TR}_{0} / \mathrm{RC}$ of all ecotypes increased (Table 2). However, OCI160 plants showed a marginal alteration (decline and increase) in all these parameters. The higher average absorption $\left(\mathrm{ABS}_{0} / \mathrm{RC}\right)$ and the greatest values of dissipation per reaction center $\left(\mathrm{DI}_{0} / \mathrm{RC}\right)$ associated with concomitantly lower value of electron transport $\left(\mathrm{ET}_{0} / \mathrm{RC}\right)$, trapping rate $\left(\mathrm{TR}_{0} / \mathrm{RC}\right)$ per active PSII RC $\left(\mathrm{ET}_{0} / \mathrm{RC}\right)$ and the decreased number of active PSII RCs per leaf cross section, $\mathrm{RC} / \mathrm{CS}_{0}$, observed in the other accessions (OCI: 142, 148, 149, 30, 102, 118, 126) might indicate increased UV-B stress sensitivity in these plants compared to OCI160. A large increase in the value of ABS/RC can be due to the inhibition of a fraction of PSII centers acting as permanently close centers $[45,46]$, which leads to the disruption in the transport and capture of electrons by photosynthetic systems, thus a low photosynthetic performance in the sensitive ecotypes.

Similarly, the behavior of the phenomenological fluxes per cross section (ABS/ $\mathrm{CS}_{0}$, $\mathrm{TR}_{0} / \mathrm{CS}_{0}, \mathrm{ET}_{0} / \mathrm{CS}_{0}$, and $\mathrm{DI}_{0} / \mathrm{CS}_{0}$ ) under high UV-B radiation indicates a reduced overall processing of light energy with different degrees. It seems that the higher susceptibility of the majority sweet basil ecotypes (OCI: 142, 148, 149, 30, 102, 118, 126) to acute UV$\mathrm{B}$, may be related to a strong decrease in $\mathrm{ET}_{0} / \mathrm{CS}_{0}$ and $\mathrm{TR}_{0} / \mathrm{CS}_{0}$ (Figure $3 \mathrm{~B}, \mathrm{C}$ ) due to the conversion of active reaction centers into inactive reaction centers, as indicated by lower RC/CS 0 values [47], thus reducing the efficiency of trapping and the PSII activity. Furthermore, the increase of $\mathrm{DI}_{0} / \mathrm{CS}_{0}$ represents a damage of electron transfer from the PSII to the photosynthetic machinery as shown by the significantly lower values of $\mathrm{ET}_{0} / \mathrm{CS}_{0}$ in sensitive ecotypes and subsequently the energy received must be released as heat (Figure 3D). Similar results have been reported in heath plants under drought stress [40], in quinoa leaves under drought stress [48], in ornamental plants under salt stress [34] in spinach leaves under low $\mathrm{pH}$ [49] and in tomato leaf under heat stress [50].

In contrast, the most tolerant ecotype (OCI160) showed a more efficient electron transport rate and a lower level in energy dissipation which might establish a consistent flow of electrons, improve the repair of photosystem II (PSII) and facilitate the ability of the donor and acceptor sides of PSII to deliver electrons. Thus, high UV-B dose resulted in a general decrease in photosynthetic efficiency by reducing flux ratios for $\mathrm{Fv} / \mathrm{Fm}, \mathrm{TR}_{0} / \mathrm{CS}_{0}$, $\mathrm{ET}_{0} / \mathrm{CS}_{0}$, and elevated flux ratios for $\mathrm{DI}_{0} / \mathrm{CS}_{0}$ and triggering perturbations within the photosynthetic apparatus that might exceed the PSII repair capacity of sensitive ecotypes. Taken together, these results suggest that physiological parameters, associated with the 
leaf functionality of the photosynthetic machinery, may be used as reliable biomarkers to discriminate among ecotypes with a different tolerance to high UV-B light. Many investigations have reported that UV-B light stimulates the accumulation of phenolic compounds in the leaf epidermis to screen out UV damaging irradiation $[25,27,51-54]$.

O. basilicum is considered a rich source of natural phenolic compounds $[18,19,55]$ and their accumulation is strongly stimulated by UV-B light conditions [25,56-60]. In this study and in agreement with previous investigations [24,27], the main caffeic acid derivate detected at a significant level in sweet basil leaves was RA.

The accumulation of RA increased with the UV-B light treatment in OCI142, OCI148, OCI30, OCI160, and OCI102 ecotypes, with the highest concentration measured in OCI160 leaves (Figure 4). Levels of UV tolerance with respect to protection mechanisms differ considerably between genera, species, and even closely related cultivars [61]. The higher accumulation of RA in OCI160 leaves in comparison to the levels detected in other sweet basil ecotypes suggest an essential role of epidermal screening in UV protection, preventing chronic photoinhibition and promoting rapid photosynthetic recovery. The hydroxycinnamic acids are considered particularly effective in screening out UV-B radiation because they absorb effectively in the UV-B spectral region [62]. In addition, because RA has high radical-scavenging activity, its accumulation can counteract the increase in the intracellular level of ROS, preventing the damaging effect of UV-B radiation [63].

In conclusion, in O. basilicum leaves, synthesis of RA was strongly enhanced by high UV-B radiation in OCI160, showing fewer signs of UV-stress injuries compared to all other ecotypes. The other ecotypes did not increase the concentration of RA or synthesized significantly lower amounts of RA, compared to OCI160. Hence, this condition might diminish UV-B screening ability and, hence, increased susceptibility to UV-B damage, with a negative effect on photosynthetic performance. Our data indicate that UV-B-dependent inhibition of leaf functionality reported in the tolerant ecotype (OCI160), recovered in parallel to the increase of RA for UV-B radiation, suggesting that PSII is protected against damaging UV-B irradiation.

Supplementary Materials: The following are available online at https:/ /www.mdpi.com/article/10 $.3390 /$ horticulturae7050101/s1, Table S1.

Author Contributions: Conceptualization, and methodology, A.T., A.M.; formal analysis, investigation, H.M., A.T., R.M.; writing—original draft preparation, H.M., A.T., A.F., L.I., A.M.; writingreview and editing, A.F., L.I.; supervision, A.M. All authors have read and agreed to the published version of the manuscript.

Funding: This research received Scuola Superior Sant'Anna funding for Ph.D. support of Mosadegh.

Data Availability Statement: Data are archived in A. Mensuali's lab and available upon request.

Conflicts of Interest: The authors declare no conflict of interest.

\section{References}

1. Frohnmeyer, H.; Staiger, D. Ultraviolet-B Radiation-Mediated Responses in Plants. Balancing Damage and Protection. Plant. Physiol. 2003, 133, 1420-1428. [CrossRef]

2. Agrawal, S.B.; Rathore, D.; Singh, A. Combined effects of enhanced ultraviolet-B radiation and mineral nutrients on growth, biomass accumulation and yield characteristics of two cultivars of Vigna radiata L. J. Environ. Biol. 2006, $27,55-60$.

3. Pandey, J.; Chaplot, K. Effects of enhanced UV-B radiation on physiological and biochemical characteristics of wheat. Res. Crops 2007, 8, 401-405.

4. Yao, X.; Liu, Q. Changes in morphological, photosynthetic and physiological responses of Mono Maple seedlings to enhanced UV-B and to nitrogen addition. Plant. Growth Regul. 2006, 50, 165-177. [CrossRef]

5. Hu, Z.; Li, H.; Chen, S.; Yang, Y. Chlorophyll content and photosystem II efficiency in soybean exposed to supplemental ul-traviolet-B radiation. Photosynthetica 2013, 51, 151-157. [CrossRef]

6. He, Y.-Y.; Häder, D.-P. Involvement of reactive oxygen species in the UV-B damage to the cyanobacterium Anabaena sp. J. Photochem. Photobiol. B Biol. 2002, 66, 73-80. [CrossRef] 
7. Zhang, X.-R.; Chen, Y.-H.; Guo, Q.-S.; Wang, W.-M.; Liu, L.; Fan, J.; Cao, L.-P.; Li, C. Short-term UV-B radiation effects on morphology, physiological traits and accumulation of bioactive compounds in Prunella vulgaris L. J. Plant. Interact. 2017, 12, 348-354. [CrossRef]

8. Trivellini, A.; Lucchesini, M.; Maggini, R.; Mosadegh, H.; Sulca Villamarin, T.S.; Vernieri, P.; Mensuali-Sodi, A.; Pardossi, A. La-miaceae phenols as multifaceted compounds: Bioactivity, industrialprospects and role of "positive-stress". Ind. Crops Prod. 2016, 83, 241-254. [CrossRef]

9. Kalaji, H.M.; Jajoo, A.; Oukarroum, A.; Brestic, M.; Zivcak, M.; Samborska, I.A.; Cetner, M.D.; Łukasik, I.; Goltsev, V.; Ladle, R.J. Chlorophyll a fluorescence as a tool to monitor physiological status of plants under abiotic stress conditions. ACTA Physiol. Plant. 2016, 38, 1-11. [CrossRef]

10. Govindjee, R. Sixty-three years since Kautsky: Chlorophyll a fluorescence. Aus. J. Plant Physiol. 1995, 22, 131-160. [CrossRef]

11. Stirbet, A.; Govindjee, R. On the relation between the Kautsky effect (chlorophyll a fluorescence induction) and Photosystem II: Basics and applications of the OJIP fluorescence transient. J. Photochem. Photobiol. B Biol. 2011, 104, 236-257. [CrossRef]

12. McKay, D.L.; Blumberg, J.B. A review of the bioactivity and potential health benefits of peppermint tea (Mentha piperita L.). Phytother. Res. 2006, 20, 619-633. [CrossRef]

13. Wojdylo, A.; Oszmianski, J.; Czemerys, R. Antioxidant activity and phenolic compounds in 32 selected herbs. Food Chem. 2007, 105, 940-949. [CrossRef]

14. Carović-Stanko, K.; Orlić, S.; Politeo, O.; Strikić, F.; Kolak, I.; Milos, M.; Satovic, Z. Composition and antibacterial activities of essential oils of seven Ocimum taxa. Food Chem. 2010, 119, 196-201. [CrossRef]

15. Boffetta, P.; Couto, E.; Wichmann, J.; Ferrari, P.; Trichopoulos, D.; Bueno-De-Mesquita, H.B.; Van Duijnhoven, F.J.B.; Büchner, F.L.; Key, T.; Boeing, H.; et al. Fruit and Vegetable Intake and Overall Cancer Risk in the European Prospective Investigation Into Cancer and Nutrition (EPIC). J. Natl. Cancer Inst. 2010, 102, 529-537. [CrossRef] [PubMed]

16. Zabka, M.; Pavela, R.; Prokinova, E. Antifungal activity and chemical composition of twenty essential oils against significant indoor and outdoor toxigenic and aeroallergenic fungi. Chemosphere 2014, 112, 443-448. [CrossRef]

17. Bozin, B.; Mimica-Dukic, N.; Simin, N.; Anackov, G. Characterization of the volatile composition of essential oils of some la-miaceae species and the antimicrobial and antioxidant activities of the entire oils. J. Agric. Food Chem. 2000, 54, 1822-1828. [CrossRef] [PubMed]

18. Petersen, M.; Simmonds, M.S. Rosmarinic acid. Phytochemistry 2003, 62, 121-125. [CrossRef]

19. Makri, O.; Kintzios, S. Ocimum sp. (Basil): Botany, Cultivation, Pharmaceutical Properties, and Biotechnology. J. Herbs, Spices Med. Plants 2007, 13, 123-150. [CrossRef]

20. Labra, M.; Miele, M.; Ledda, B.; Grassi, F.; Mazzei, M.; Sala, F. Morphological characterization, essential oil composition and DNA genotyping of Ocimum basilicum L. cultivars. Plant. Sci. 2004, 167, 725-731. [CrossRef]

21. Vieira, R.F.; Grayer, R.J.; Paton, A.; Simon, J.E. Chemical characterization of basil (Ocimum spp.) based on volatile oils. Flav. Frag. J. 2006, 21, 214-221. [CrossRef]

22. Prakash, V. Leafy Spices; Apple Academic Press: Palm Bay, FL, USA, 2019; p. 114.

23. Marotti, M.; Piccaglia, R.; Giovanelli, E. Differences in Essential Oil Composition of Basil (Ocimum basilicumL.) Italian Cultivars Related to Morphological Characteristics. J. Agric. Food Chem. 1996, 44, 3926-3929. [CrossRef]

24. Kiferle, C.; Lucchesini, M.; Mensuali-Sodi, A.; Maggini, R.; Raffaelli, A.; Pardossi, A. Rosmarinic acid content in basil plants grown in vitro and in hydroponics. Open Life Sci. 2011, 6, 946-957. [CrossRef]

25. Mosadegh, H.; Trivellini, A.; Ferrante, A.; Lucchesini, M.; Vernieri, P.; Mensuali, A. Applications of UV-B lighting to enhance phenolic accumulation of sweet basil. Sci. Hortic. 2018, 229, 107-116. [CrossRef]

26. Murashige, T.; Skoog, F. A Revised Medium for Rapid Growth and Bio Assays with Tobacco Tissue Cultures. Physiol. Plant. 1962, 15, 473-497. [CrossRef]

27. Mosadegh, H.; Trivellini, A.; Lucchesini, M.; Ferrante, A.; Maggini Vernieri, P.; Mensuali Sodi, A. UV-B physiological changes under conditions of distress and eustress in sweet basil. Plants 2019, 8, 396. [CrossRef] [PubMed]

28. Maggini, R.; Tozzini, L.; Pacifici, S.; Raffaelli, A.; Pardossi, A. Growth and accumulation of caffeic acid derivatives in Echinacea angustifolia DC. var. angustifolia grown in hydroponic culture. Ind. Crop. Prod. 2012, 35, 269-273. [CrossRef]

29. Srivastava, S.; Cahill-David, M.; Conlan-Xavier, A.; Adholeya, A. A novel in vitro whole plant system for analysis of polyphenolics and their antioxidant potential in cultivars of Ocimum basilicum. J. Agri. Food Chem 2014, 62, 10064-10075. [CrossRef] [PubMed]

30. Melis, A. Photosystem-II damage and repair cycle in chloroplasts: What modulates the rate of photodamage in vivo? Trends Plant. Sci. 1999, 4, 130-135. [CrossRef]

31. Coffey, A.; Prinsen, E.; Jansen, M.; Conway, J. The UVB photoreceptor UVR8 mediates accumulation of UV-absorbing pigments, but not changes in plant morphology, under outdoor conditions. Plant. Cell Environ. 2017, 40, 2250-2260. [CrossRef] [PubMed]

32. Yu, G.H.; Li, W.; Yuan, Z.Y.; Cui, H.Y.; Lv, C.G.; Gao, Z.P.; Han, B.; Gong, Y.Z.; Chen, G.X. The effects of enhanced UV-B radiation on photosynthetic and biochemical activities in super-high-yield hybrid rice Liangyoupeijiu at the reproductive stage. Photosynthesis 2013, 51, 33-44. [CrossRef]

33. Wang, Z.X.; Chen, L.; Ai, J.; Qin, H.Y.; Liu, Y.X.; Xu, P.L.; Jiao, Z.Q.; Zhao, Y.; Zhang, Q. TPhotosynthesis and activity of photosystem II in response to drought stress in Amur Grape (Vitis amurensis Rupr.). Photosynthetica 2012, 50, 189-196. [CrossRef] 
34. Ferrante, A.; Trivellini, A.; Malorgio, F.; Carmassi, G.; Vernieri, P.; Serra, G. Effect of seawater aerosol on leaves of six plant species potentially useful for ornamental purposes in coastal areas. Sci. Hortic. 2011, 128, 332-341. [CrossRef]

35. Mathur, S.; Mehta, P.; Jajoo, A. Effects of dual stress (high salt and high temperature) on the photochemical efficiency of wheat leaves (Triticum aestivum). Physiol. Mol. Biol. Plants 2012, 19, 179-188. [CrossRef] [PubMed]

36. Trivellini, A.; Gordillo, B.; Rodríguez-Pulido, F.J.; Borghesi, E.; Ferrante, A.; Vernieri, P.; Quijada-Morín, N.; González-Miret, M.L.; Heredia, F.J. Effect of salt stress in the regulation of anthocyanins and color of Hibiscus flowers by digital image analysis. J. Agric. Food Chem. 2014, 62, 697-6966. [CrossRef] [PubMed]

37. Toscano, S.; Trivellini, A.; Ferrante, A.; Romano, D. Physiological mechanisms for delaying the leaf yellowing of potted geranium plants. Sci. Hortic. 2018, 242, 146-154. [CrossRef]

38. Force, L.; Critchley, C.; Van Renson, J.J.S. New fluorescence parameters for monitoring photosynthesis in plants. 1. The effect of illumination on the fluorescence parameters of the JIP-test. Photosynt. Res. 2003, 78, 17-33. [CrossRef]

39. Strasser, B.J.; Strasser, R.J. Measuring Fast Fluorescence Transients to Address Environmental Questions: The JIP-Test. In Photosynthesis: From Light to Biosphere; Springer Science and Business Media LLC: Heidelberg, Germany, 1995; pp. 4869-4872.

40. Albert, K.R.; Mikkelsen, T.N.; Ro-Poulsen, H.; Arndal, M.F.; Michelsen, A. Ambient UV-B radiation reduces PSII performance and net photosynthesis in high Arctic Salix arctica. Environ. Exp. Bot. 2011, 73, 10-18. [CrossRef]

41. Jansen, M.A.K.; Biswas, D.K. Natural variation in UV-B protection amongst Arabidopsis thaliana accessions. Emir. J. Food Agric. 2012, 24, 621-623. [CrossRef]

42. Piccini, C.; Cai, G.; Dias, M.C.; Romi, M.; Longo, R.; Cantini, C. UV-B Radiation Affects Photosynthesis-Related Processes of Two Italian Olea europaea (L.) Varieties Differently. Plants 2020, 9, 1712. [CrossRef] [PubMed]

43. Strasser, R.J.; Srivastava, A.; Tsimilli-Michael, M. The fluorescence transient as a tool to characterize and screen photosynthetic samples. In Probing Photosynthesis: Mechanisms, Regulation and Adaptation; Yunus, M., Pathre, U., Mohanty, P., Eds.; Taylor \& Francis: London, UK, 2000; pp. 445-483.

44. Strasser, R.J.; Michael, M.T.; Srivastava, A. Analysis of the chlorophyll a fluorescence transient. In Advances in Photosynthesis and Respiration; Papageorgiou, G., Govindjee, Eds.; Springer: Dordrecht, The Netherlands, 2010; Volume 19, pp. $321-362$.

45. Lu, C.; Zhang, J.; Zhang, Q.; Li, L.; Kuang, T. Modification of photosystem II photochemistry in nitrogen deficient maize and wheat plants. J. Plant. Physiol. 2001, 158, 1423-1430. [CrossRef]

46. Castro, F.A.; Campostrini, E.; Torres-Netto, A.; Viana, L.H. Relationship between photochemical efficiency (JIP-test param-eters) and portable chlorophyll meter readings in papaya plants. Braz. J. Plant. Physiol. 2011, 23, 295-304. [CrossRef]

47. Mehta, P.; Jajoo, A.; Mathur, S.; Bharti, S. Chlorophyll a fluorescence study revealing effects of high salt stress on Photosystem II in wheat leaves. Plant. Physiol. Biochem. 2010, 48, 16-20. [CrossRef] [PubMed]

48. Fghire, R.; Anaya, F.; Ali, O.I.; Benlhabib, O.; Ragab, R.; Wahbi, S. Physiological and photosynthetic response of quinoa to drought stress. Chil. J. Agric. Res. 2015, 75, 174-183. [CrossRef]

49. Tongra, T.; Mehta, P.; Mathur, S.; Agrawala, D.; Bhartia, S.; Los, D.A.; Allakhverdiev, S.L.; Jajoo, A. Computational analysis of fluorescence induction curves in intact spinach leaves treated at different pH. Biosystems 2011, 103, 158-163.

50. Zushi, K.; Kajiwara, S.; Matsuzoe, N. Chlorophyll a fluorescence OJIP transient as a tool to characterize and evaluate response to heat and chilling stress in tomato leaf and fruit. Sci. Hortic. 2012, 148, 39-46. [CrossRef]

51. Kolb, C.A.; Käser, M.A.; Kopecký, J.; Zotz, G.; Riederer, M.; Pfündel, E.E. Effects of natural intensities of visible and ultraviolet radiation on epidermal ultraviolet screening and photosynthesis in grape leaves. Plant Physiol. 2001, 127, 863-875. [CrossRef] [PubMed]

52. Liu, Y.; Liu, J.; Abozeid, A.; Wu, K.-X.; Guo, X.-R.; Mu, L.-Q.; Tang, Z.-H. UV-B Radiation Largely Promoted the Transformation of Primary Metabolites to Phenols in Astragalus mongholicus Seedlings. Biomolecules 2020, 10, 504. [CrossRef]

53. Rácz, A.; Czégény, G.; Csepregi, K.; Hideg, É. Ultraviolet-B acclimation is supported by functionally heterogeneous phenolic peroxidases. Sci. Rep. 2020, 10, 1-13. [CrossRef]

54. Del Valle, J.C.; Buide, M.L.; Whittall, J.B.; Valladares, F.; Narbona, E. UV radiation increases phenolic compound protection but decreases reproduction in Silene littorea. PLoS ONE 2020, 15, e0231611. [CrossRef] [PubMed]

55. Marwat, S.K.; Khan, M.S.; Ghulam, S.; Anwar, N.; Mustafa, G.; Usman, K. Phytochemical constituents and pharmacological activities of sweet Basil-Ocimum basilicum L. (Lamiaceae). Asian J. Chem. 2011, 23, 3773.

56. Bertoli, A.; Lucchesini, M.; Mensuali-Sodi, A.; Leonardi, M.; Doveri, S.; Magnabosco, A.; Pistelli, L. Aroma characterisation and UV elicitation of purple basil from different plant tissue cultures. Food Chem. 2013, 141, 776-787. [CrossRef]

57. Ghasemzadeh, A.; Ashkani, S.; Baghdadi, A.; Pazoki, A.; Jaafar, H.Z.E.; Rahmat, A. Improvement in Flavonoids and Phenolic Acids Production and Pharmaceutical Quality of Sweet Basil (Ocimum basilicum L.) by Ultraviolet-B Irradiation. Mollecules 2016, 21, 1203. [CrossRef] [PubMed]

58. Sakalauskaite, J.; Viskelis, P.; Duchovskis, P.; Dambrauskiene, E.; Sakalauskiene, S.; Samuoliene, G.; Brazaityte, A. Supple-mentary UV-B irradiation effects on basil (Ocimum basilicum L.) growth and phytochemical properties. J. Food Agric. Environ. 2012, 10, 342-346.

59. Sakalauskaite, J.; Viskelis, P.; Dambrauskiene, E.; Sakalauskiene, S.; Samuoliene, G.; Brazaityte, A.; Duchovskis, P.; Ur-bonaviciene, D. The effects of different UV-B radiation intensities on morphologicaland biochemical characteristics in Ocimum basilicum L. J. Sci. Food Agric. 2013, 93, 1266-1271. [CrossRef] [PubMed] 
60. Nitz, G.M.; Schnitzler, W.H. Effect of PAR and UV-B radiation on the quality and quantity of the essential oil in sweet basil (Ocimum basilicum L.). In Proceedings of the VII IS on Protocol Culture Mild Winter Climates; Cantliffe, D.J., Stoffella, P.J., Shwa, N., Eds.; Acta Horticulturae: Kissimmee, FL, USA, 2004; Volume 659, pp. 375-382.

61. Jansen, M.A.K.; van den Noort, R.E.; Adillah Tan, M.Y.; Prinsen, E.; Lagrimini, L.M.; Thorneley, R.N.F. Phenol-Oxidizing Pe-roxidases Contribute to the Protection of Plants from Ultraviolet Radiation Stress. Plant Physiol. 2001, 126, 1012-1023. [CrossRef]

62. Landry, L.G.; Chapple, C.; Last, R.L. Arabidopsis Mutants Lacking Phenolic Sunscreens Exhibit Enhanced Ultraviolet-B Injury and Oxidative Damage. Plant. Physiol. 1995, 109, 1159-1166. [CrossRef] [PubMed]

63. Lee, H.J.; Cho, H.S.; Park, E.; Kim, S.; Lee, S.Y.; Kim, C.S.; Kim, D.K.; Kim, S.J.; Chun, H.S. Rosmarinic acid protects human dopa-minergic neuronal cells against hydrogen peroxide-induced apoptosis. Toxicology 2008, 250, 15-109. [CrossRef] 